\title{
The Japanese Character and its Peculiarity - A Study of Carl Peter Thunberg's Travel Account
}

\author{
Leonie Kijewski
}

\section{Introduction}

Today, a large number of European citizens spend their holidays abroad. In Germany, for example, long-term holidays spent abroad made up more than $60 \%$ of all long-term holidays from the German population in 2011. In Belgium, this percentage even ranged up to $88 \%$ (Eurostat, 2012). But how did travelling look like in earlier eras? From the sixteenth century onward, travelling abroad became popular for academic purposes. However, not only scientists, but also missionaries and commercial travelers took up their journey to different parts of the world. And - like today - they shared their experience with persons that were interested in foreign cultures. Thus, an increasing number of travel reports were published from the sixteenth century onward (Jung, 2002). At that stage, the greatest number of travels took place within Europe. Nevertheless, also other parts of the world attracted numerous travelers.

Japan was one of the countries of destination. However, with its increasing isolation in the 1630 - cumulating in the ban of all foreigners apart from Chinese and Dutch traders and restricting Dutch traders to the small artificial island Deshima in 1641 - only few foreigners received permission to enter the country (Rietbergen, 2003, p. 170). Since their travels were based on monetary and rarely on scientific interests, only a small number of 
travel accounts about Japan were published in the seventeenth and eighteenth centuries (Rietbergen, 2004, p. 56). When the Swedish botanist Carl Peter Thunberg (1743-1828) published his Resa uti Europa, Africa, Asia, förrättad åren 1770 - 1779 from 1788 onwards, it were around fifty years that no new narratives on Japan had been published in Europe'. Thus, it is of no surprise that his travel account was widely read in Europe. Thunberg's work was translated once into English and Japanese, twice into French and twice into German (Screech, 2005, pp. 61-62).

Despite aiming for a neutral report about the Japanese society, Thunberg provides a personal account about the Japanese that is remarkably positive and entails only few negative comments (e.g. too strict obedience to rules). This paper answers the question in how far and in what way Thunberg sets the Japanese culture and society apart from the European one. Moreover, possible reasons for this positive account are given. This chapter works with the English translation by Charles Hopton of 1793-95, which was reedited in 2005 by Timon Screech. The page numbers that are given in this chapter are derived from the 2005 edition. The German original translation by Kurt Sprengel from 1792 can be found in Maastricht Jesuit collection and is also referred to in this chapter.

\section{Thunberg's Journey}

Carl Peter Thunberg finished his studies of surgery and botany in 1767 , and his well-known teacher Carl Linnaeus recommended traveling abroad to continue medical studies there. ${ }^{2}$ Following this advice, Thunberg decided to travel to the Netherlands and France after his doctorate in philosophy. He was by no means the only student of Linnaeus who travelled abroad; instead, seventeen of Linnaeus' most promising students travelled to America, Africa and Asia to test the universality of the binary nomenclature that had been invented by their master ${ }^{3}$. These travelers are often referred to as the "Linnaeus Apostles", Thunberg being one of them (Hansen et al., 2007).

1 This last travel account was published by Engelbert Kaempfer in 1727. His travel already took place between 1690 and 1692.

2 Linné, Carl (1707-1778), a famous Swedish natural scientist who invented the binary nomenclature that is still in use today. He encouraged his students to verify this system by travelling abroad. As Rietbergen (2004) puts it, "Linnaeus can be termed one of the fathers of the phenomenon of the scientific expedition" (p. 52).

3 See, for a complete list “The Linnaeus apostles: global science an adventure”, Vol. 1-8, The IK Foundation \& Company (cf. http://www.ikfoundation.org/downloads/LACompleteCatalogueCopyrightIK2.pdf). 
In Amsterdam, Thunberg met the professor of botany Johannes Burman (1707-1779) and his son Nicolaas Laurens who brought his attention to the possibility of exploring Japan. ${ }^{4}$ They offered to organize his travel. In return, he would do research in Japan, collect seeds and plants and send them to Burman and Linnaeus. By doing that, Thunberg could contribute to the knowledge about the Japanese flora, which was largely unknown in Sweden and the Netherlands at that time. The Royal Swedish Academy of Science therefore supported scientific travels by providing future travelers with important contacts. Moreover, Thunberg received small funds by the Academy of Science during his residence at the Cape (Rudner, 1986, p. xiii).

At that time Sweden held one of the leading positions in science in Europe, which was partly due to the famous scientist Linnaeus (Skott, 2010, p. 361). Linnaeus supported Thunberg's plans and hoped that Thunberg could help classifying earlier botanic findings in the new Linnaean system. Since Linnaeus had contact to the Dutch East India Company (VOC), he advised his students to use these contacts to travel abroad (ibid.).

However, Thunberg's travels were not only in the interest of Linnaeus and contributing to the Swedish scientific reputation. When Thunberg published his Travels from 1788 onwards, nearly hundred years had passed since Engelbert Kaempfer travelled to Japan and wrote his travel account History of Japan. ${ }^{5}$ Accordingly not only the scientists of Sweden, but also the general population in Europe was curious to receive new information about this country. At the time of Thunberg's journey, travels into other countries were becoming popular among an increasing part of the population. From the sixteenth century onwards, mainly noblemen with sufficient monetary resources were travelling around Europe - above all to Italy and France - to enrich their knowledge and increase their reputation (Jung, 2002). In order to give the public access to a hitherto unknown world, great importance was attached to not only travelling abroad, but also taking notes and publishing them upon return.

Towards the end of the eighteenth century, also the bourgeoisie travelled around Europe. Since at that time expeditions within Europe were not considered exceptional anymore, no significant reputation could be gained through gaining experience within Europe. In contrast, unexplored countries outside of Europe could promise an advance in one's career. Thunberg chose Japan as his country of destination and therefore travelled to an area which was largely unknown. Since travel reports were popular at that time, Thunberg could be next to certain that his travel account would be widely read in Europe (Jung, 2002, p. 65).

4 Linnaeus himself had been an assistant to Johannes Burman in the 1730s (Skott, 2010).

5 For a detailed analysis of Kaempfer's stay in Japan see chapter 7 of this volume. 
The only European enterprise that had access to Japan was the VOC. This company had secured exclusive trading rights with Japan in the 1630 s and was therefore the only way by which Japan could be reached. Individual travelers were not allowed into the country (Rietbergen, 2003, p. 170). To pass as a Dutchman, Thunberg set out to Africa with the VOC in spring 1772, where he carried out his first field research while learning Dutch. An additional reason for serving as a surgeon on the ship and, later, on Deshima might have been that Sweden was in an economically weak position at that time (Kent, 2008). Holding a paid job for several years might have been advantageous in a time where finding permanent employment was difficult.

After three years, he continued his journey and went to Batavia. In June 1775, Thunberg took up his journey to Japan with the VOC and arrived there in August of the same year. There, he was principally employed as physician. Nevertheless, he spent most of his time researching and collecting plants, since his occupation as a doctor did not require a great amount of time (Thunberg, 2005, p. 104). Thunberg was the only Linnaeus apostle who travelled to Japan, staying there nineteen months. To establish how his academic background influenced the travels and vice versa, Thunberg's biography is set out in the next section.

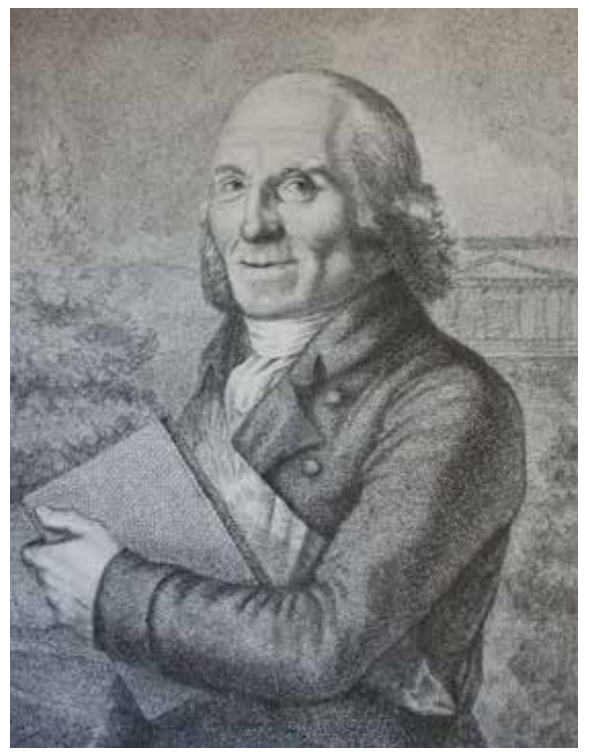

Fig. 1: Carl Peter Thunberg at the Age of 65

Source: Peter Krafft the Younger (n.d.), University Art Museum Collection, Uppsala. 


\section{Biography of Carl Peter Thunberg}

Carl Peter Thunberg was born in 1743 in Jönköping and passed away near Uppsala in 1828. He grew up in the southern Swedish region Småland in a rather modest household. ${ }^{6}$ In 1762 he entered his studies of theology, philosophy and law at the University of Uppsala, which was the most distinguished seat of learning at that time (Screech, 2005). ${ }^{7}$ However, he switched to the studies of botany and surgery and became a student of Carl Linnaeus. In 1767 , he received the doctorate in philosophy from Linnaeus and in 1772 - in absentia because he was travelling - his doctorate in medicine.

After his doctorate in philosophy, he travelled to Amsterdam in 1770, where he stayed for a brief period of time only. At the end of the same year, he went to Paris but returned to Amsterdam already eight months later. This was most likely linked to the fact that the crown prince Gustaf - who had been staying in Paris until then - left for kingship in Sweden; hence, the importance of Paris decreased. ${ }^{8}$

Thunberg's travels most likely served to advance his career (Screech, 2005, pp. 2, 18). Upon his return to Sweden in 1779 (after having passed through Batavia, the Netherlands and the England), Thunberg began teaching at the University of Uppsala. Carl Linnaeus' son - also called Carl - had taken over his father's seat as the director of the Hortus Botanicus. Thunberg took over this renowned position when Carl the younger unexpectedly died in 1783 (Screech, 2005, p. 13). Moreover, Thunberg was now considered "spokesperson for Japan across all of northern Europe" (ibid.). Further, Thunberg became president of the Swedish Royal Academy of Science (ibid., p. 14). Thus, Thunberg's strategy of advancing his career by travelling to Japan turned out to be very successful.

Being occupied with teaching and holding the directorate of the Hortus Botanicus, it took some time for Thunberg to write his travel report. It was only ten years after his return that Thunberg published his Travels. After a long career as professor at Uppsala, during which he published numerous books and articles, he passed away in 1828 .

6 Information about Thunberg's biography is retrieved from Screech (2005, pp. 4-8) and Jung (2002, pp. 17-37), unless stated otherwise.

7 There is diverging opinion on his actual entry into the University of Uppsala. According to Rietbergen (2004), he took up his studies one year earlier in 1761.

8 Thunberg dedicated his Travels to King Gustaf III (Thunberg, 1788). This indicates how connected he felt toward his home country. 


\section{Publishing the Travels}

On his return to Sweden, Thunberg first published several books on the flora and fauna of Japan before writing his Travels. Anders Sparrman (1748-1820) - another student of Linnaeus - had already extensively published on the flora and fauna at the Cape, Thunberg therefore saw Japan as a chance to provide new knowledge about an unknown country and gain reputation in the academic field (Screech, 2005, pp. 2, 18). Thus, he focused on Japan instead of the Cape, despite having stayed at the latter for a far longer period of time.

In 1788, his Resa uti Europa, Africa, Asia, förrättad åren 1770-1779 began to appear. The fourth and last volume was published in 1793. The first and second volumes deal with his stay in the Netherlands and France, at the Cape, and on Java. The third volume describes Thunberg's journey to and stay in Japan. It was published in 1791. This third volume of his Travels is the volume this chapter is focusing on. The fourth volume is structured in a different way than the previous volumes. It consists of rather short essays that deal with his whole journey and summarize his findings about the flora and fauna, geography and culture of the countries he has been travelling to. So, Thunberg's travel account consists of four volumes, three of which are mostly written in a chronological order, the fourth being written in an encyclopedic manner. The original is scarcely illustrated. All illustrations can be found in the fourth volume of the original and were recopied into the English and first German translation. The illustrator was his pupil Jonas Niclas Ahl.

Translations of his work followed shortly after. ${ }^{9}$ First, an abridged German version was published in 1792. This version was published in Berlin by Christian Voß and translated by the German scientist Kurt Sprengel. In 1792-94, Christian Groskurd provided a more extensive, albeit also shortened, translation of Thunberg's work. This version has been reedited by Eberhard Friese and was published 1991 in two volumes. In 1794, a French translation was published that was oriented toward the German translation by Kurt Sprengel (Thunberg, 1794 (French edition), p. VI). Two years later, in 1796, a fuller French version by Louis-Mathieu Langlès appeared (this version was reissued by Claude Gandon in 1966). An English translation was issued in four volumes in 1793-95 by an anonymous translator. It is, however, securely established that this translator was the physician and medical writer Charles Hopton (Screech, 2005). These four volumes were only slightly cut and stuck to the same structure as the original. Notably, no Dutch translation of the Travels was ever made, although Thunberg had contacts to the Netherlands and spoke the language fluently. Further, it was only until the early twentieth century that the first

9 For more information on the publishing history, see Screech (2005) pp. 61-63. 
Japanese translation appeared. This was limited to volume three and relevant parts on Japan of volume four (Screech, 2005, p. 63).

The majority of the translated versions set a focus on the travel to Japan: In the shortened version of 1792, the publisher added vorzüglich (especially) to the title. The title of the longer German version was extended by the word hauptsächlich (mainly). Similarly, the first French translation stated principalement, whereas the second one simply titled the work as Voyage de C.P. Thunberg au Japon (1796). The historian William Mavor (1809) claims that this was due to the belief that most readers would take greater interest in Japan than in Africa. Thunberg had been the first scientist reporting about Japanese culture and the flora and fauna after Kaempfer. Moreover, Kaempfer did not write about language and only to a limited extent about Japanese culture (cf chapter 7 about Kaempfer of this volume). Thus, publishers believed that setting the focus on Japan would increase the sales quote (Screech, 2005). The English version sticks closer to the original by titling it Travels in Europe, Asia and Africa made during the Years 1770 \& 1779.

\section{Content and Structure of the Travels}

By writing both in a chronological and in an encyclopedic way (see above), Thunberg combines the two most common methods of writing travel accounts from that period of time (Jung, 2002, p. 85). The chronological part consists of the first four chapters of Volume 3 of the Swedish original. It can be divided into five parts: the travel to Nagasaki, his life on the island Deshima, the travel to the Court of Edo (today: Tokyo), his stay there (including the travel back to Nagasaki), and a general description about the Japanese.

In the first brief part (Thunberg, 2005, pp. 71-80), he reports about the journey from Batavia to Japan and introduces the strict trading and inspection rules of the Japanese to the reader. In the second part (ibid., pp. 81-105), Thunberg mostly describes his life on the island, the trade between Dutch and Japanese and the Chinese trade. Apart from one journey to Edo, Thunberg was seldom allowed to leave the island and Nagasaki. Despite comparing the island Deshima with a prison (ibid., p. 104), he depictures the Japanese in a positive way. He states that the reason for the harsh treatment by the Japanese lies in the behavior of the Europeans (see section 6). 


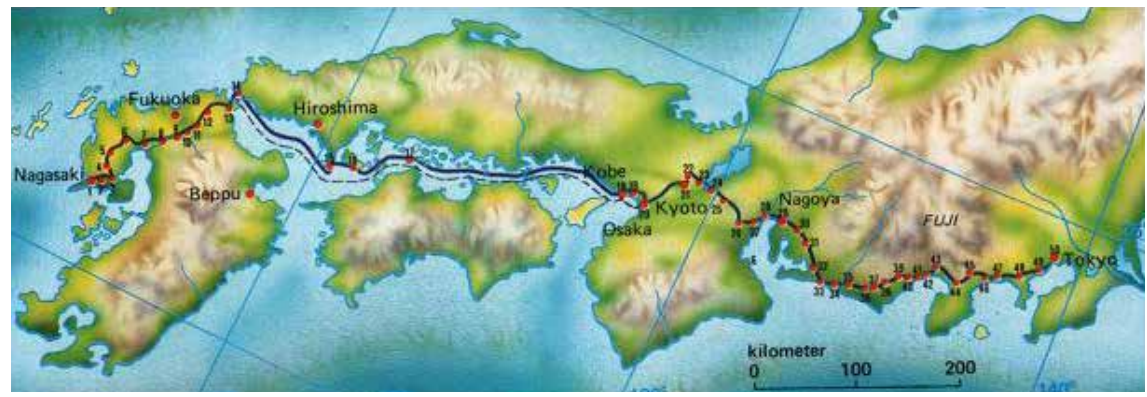

Fig. 2: Thunberg's travel to the court of Edo.

Source: Wallström, T. (1982), Thunberg's travels in Japan. Svenska upptäckare. Stockholm: Trevi.

In the third part (ibid., pp. 106-135), he focuses on nature but also writes down some observations of Japanese culture. When travelling to the Court, he is pleased by the respectful treatment of the Japanese toward him. Further, Thunberg is delighted by the cleanliness of the accommodations. In the fourth part (ibid., pp.136-156), the reader learns about Japanese scientists and the political elite. Thunberg sets a focus on the scientific lessons he gives the Japanese and outlines the curiosity of the Japanese. Moreover, Thunberg accounts for parts of the Japanese culture, such as religion and the relationship between men and women.

With the fifth section of Volume 3 (ibid., pp. 157-171), the encyclopedic part begins. It is structured differently than the other parts: instead of giving a chronological account of his journey, he groups the information according to thematic belonging: he describes the geography of the country, the persons (including the character and political structure of the state), the Japanese language, the Japanese names, the clothing and the architecture.

Volume 4 (ibid., pp. 172-218) - which was published in the Swedish original as a separate volume but combined with the third volume in the newer English edition of 2005 - is divided into several sections: the government, weapons, religion, food, drinks, the smoking of tobacco, sports and games, sciences, law and police, physicians, agriculture, commerce, and - set apart - his residence on the island upon his return from the journey to the court.

When analyzing Thunberg's travel account, it becomes apparent that his descriptions are largely positive; he considers only a few elements as negative (with a slightly more negative image depictured in the translation by Sprengel, as explained below). The following section elaborates in detail on the way how Thunberg represents the Japanese. 


\section{The Japanese Character}

In his Travels, Thunberg does not merely deliver an objective account of Japan's flora and fauna, but also writes about Japanese culture, language and politics. The way he does so has been described as fitting into the "typical Enlightenment style" (Rietbergen, 2004, p. 54) by attempting to leave subjective thoughts aside and providing the reader with insights that are not merely based on his own perception but are representing an objective reality. To distinguish oneself from "self-serving, vulgar travelers" (Jung, 2002, p. 71), one was advised to write travel reports that were as objective as possible and at the same time providing new information As Iggers and Wang claim, this approach is based on modern enlightened values that emerged in the West and were slowly adopted also in Asian countries. The eighteenth century was marked by a changing view of the world: it was a turn away from the Biblical understanding of the world towards a critical analysis of sources (Iggers \& Wang, 2008, p. 21). In these lines, Thunberg's approach can be viewed as representing that century's rationalism.

This commitment to objectivity can be seen in his attempts to give reasons for every estranging experience he notes down. In these lines, he writes that the Japanese isolation is due to earlier hostile behavior by Europeans and can therefore be explained rationally. However, one can still discover a subjective view on 'the Other' when analyzing his writing. The aim of this chapter is to investigate the way in which Thunberg differentiates "the Japanese" from "the European." Thunberg mostly had contact to the interpreters and intellectuals in Japan and less to other parts of the population. Nevertheless, Thunberg does not differentiate between different classes and generalizes when referring to "the Japanese."

Throughout his work, Thunberg presents the character of the Japanese in a rather positive way. In the following, I examine how Thunberg presents "the Japanese" by focusing on his descriptions of the character. Although he not only describes the character but also food, clothes and the like, the former is the concept that is the most present in his travel account. In both the chronological and the encyclopedic part Thunberg refers to the Japanese character.

To structure the analysis, I focus on those traits of character that Thunberg mentions often in relation to the Japanese: their curiosity and admiration of European knowledge; and their strict obedience to rules. 


\title{
Curiosity and Admiration of European Knowledge
}

One trait of character that Thunberg claims to be common to all Japanese is curiosity, including the eagerness to acquire knowledge. In these lines, he writes that

\begin{abstract}
"the interpreters are extremely fond of European books.... They are not only in possession, but make diligent use of them and retain strongly in their memory what they learn from them. They are besides very careful to learn something from the Europeans and question them without ceasing, and frequently so as to be irksome, upon all subjects." (Thunberg, 2005 p. 91)
\end{abstract}

It is important to note that Thunberg shows his appreciation for the eagerness to learn European knowledge. He welcomes the curiosity of the Japanese when this relates to European science, but nowhere in the travel account are any other forms of knowledge mentioned. Instead, Thunberg focuses on his scientific instructions to the Japanese. Despite looking down at their level of knowledge, he shows admiration for their capacity of remembering things he taught them.

The reason for this positive attitude toward the Japanese intellectuals lies most likely in two reasons. First, it could be based on what Jung (2002) describes as the will to present oneself as part of the academic world: "At that time, it was of utmost importance for an academic to be able to present himself as part of the erudite world" (p. 160). Hence, Thunberg uses the travelogue to emphasize his contact with Japanese scientists. Examples for this are numerous in his travel account, but one keynote is presented here:

"My pupils requested from me a certificate with respect to the instructions I had given them.... I therefore gave them one, written in Dutch, which made them so immensely happy and proud.... I had the good fortune to gain their love and friendship to such a degree that they did not only set a high value on my knowledge and on my kindness in communicating that knowledge to them, but they loved me from the bottom of their hearts, so as greatly to regret my departure. Since this, during a period of several years, I have not only kept up an intercourse by letters with them ... but likewise sent them some small but acceptable presents, and received in return both seeds for the botanical garden at Upsal, and some additions to the academy's collection of natural history." (Thunberg, 2005, p. 165) 
This quote shows that both his knowledge and his personality are appreciated by the Japanese. Moreover, Thunberg implicitly points out the usefulness of the contact he gained in Japan for the Swedish botanic world. Since the Japanese flora and fauna was largely unknown at the end of the eighteenth century in Sweden (Jung, 2002), receiving seeds for the botanical garden could both increase the reputation of the botanical garden at Uppsala and add to the knowledge about botany.

What is striking here is that he claims to have gained "their love and friendship" and they "loved [him] from the bottom of their hearts." This observation seems to stand in contrast with his earlier statement:

"How much so ever the Europeans are despised in their factory, and in however contemptible a light the Japanese are used to consider all foreigners, yet it is not more surprising than true that in the course of our journey to and from the court we were everywhere received not only with the greatest politeness and attention, but with the same respect and esteem as is shown to the princes of the country when they make their journeys to the imperial court." (Thunberg, 2005, p. 122)

Jung (2002) gives reason for this disdain of the Japanese towards the Europeans. In $18^{\text {th }}$ century Japan, salesmen were the lowest rank in the societal hierarchy. Since most of the Europeans that came to Japan were traders, it is understandable that the Japanese might consider them to be of a lower rank. Perhaps that was a reason why Thunberg was to be exempted from their despisement. But why and how Thunberg was able to establish the "true love" remains unclear.

The second reason for his positive attitude is also illustrated by the key quote. Although Thunberg admires the Japanese for certain traits of character, he considers Europeans as superior in several aspects. This applies in particular to the sciences, where he views Japanese as backward. In these lines, Thunberg writes: "The Japanese nation shows sense and steadiness in all its undertakings, so far as the light of science, by whose brighter rays it has not as yet had the good fortune to be illumined, can ever guide it" (ibid., p. 179).

That Thunberg does not hand out the certificate in Japanese (translated by his interpreters) but in Dutch, a language that is rather foreign to the Japanese and would not be understood by patients of the Japanese doctors, probably shows that he believes his European scientific knowledge to be of more value. Thus, Thunberg gladly acknowledges the attempts made by the Japanese to acquire European knowledge. Nevertheless, it should not be forgotten that it were the Japanese who demanded such a certificate and, according to Thunberg, appreciated it highly; European scientists seem to enjoy 
high reputation in Japan, in contrast to the general disdain from the Japanese toward Europeans. Consequently, Thunberg finds many occasions to bring European knowledge to either the interpreters or scientists and enjoys this role. Thus, he claims self-confidently that he had been useful to the whole Japanese nation by providing doctors with new insights into medical practices (Thunberg, 2005, p. 163). ${ }^{10}$ This seems to be in line with presenting himself in a positive way to gain reputation in Europe. Nevertheless, while believing in European superiority of science, Thunberg is by no means disinterested in Japanese culture and science. On his journey to Edo, he writes that

"With respect to such of them as were my friends, I filled up their time by giving them lectures on the art of healing, and sometimes by questions about their country, its government, and regulations in point of rural economy, but particularly with respect to language, which furnished me with the means of entirely completing the vocabulary I had previous to this period already begun." (p. 128)

Hence, Thunberg depicts a positive image of the Japanese character with regards to the willingness to learn European scientific knowledge.

\section{Strict Obedience to Rules and Commitment to Justice}

Another trait of character that Thunberg ascribes to the Japanese is the sense for justice and strict obedience to rules. Despite generally admiring the strict obedience to rules and superiors, Thunberg views this characteristic of the Japanese partially negative. This two-fold viewpoint can be illustrated by comparing two quotes. In the fourth volume of his Travels, Thunberg gives insight into the character of the Japanese and describes the subordination to superiors as having positive consequences.

10 Interestingly, the parts in which Thunberg gives account for his own position in the Japanese society and describes how helpful he was to Japanese society are left out in the translation by Kurt Sprengel. In these lines, Thunberg writes while on his stay in Edo that he gave important medical information to the Japanese that "may hereafter prove of inestimable utility to a whole nation" (Thunberg, 2005, p. 163). This statement was left out by Sprengel; the reason for this might be that first, Sprengel - in contrast to Thunberg - had no interest in increasing Thunberg's reputation. Second, it might have been believed that leaving this statement out would increase credibility. 
"With respect to courtesy and submission to their superiors, few can be compared to the Japanese. Subordination to government and obedience to their parents are inculcated into children in their early infancy, and in every situation of life they are in this respect instructed by the good example of their elders, which has this effect: that the children are seldom reprimanded, scolded or chastised." (Thunberg, 2005, p. 160)

This seems to be an indirect critique to the European educational system. At that time, despite moving away from understanding children as "small adults", the European educational system was based on punishment (Neumann, 2002, p. 16). Thunberg appreciates the Japanese educational system; according to him, this is based on strict obedience to parents, but punishment is used only rarely, which stands in contrast to the European educational methods.

Nevertheless, Thunberg sets this strict obedience not only in a positive light. To increase his knowledge about Japan's flora and fauna, Thunberg sought permission to botanize in Nagasaki. At first, he was successful, but after a short period of time the allowance was redrawn, based on the reason that no surgeon of his position had ever received this permission before (Thunberg, 2005 p. 93). In his travel account, Thunberg expresses his lack of understanding for this action.

"The motive for this was ridiculous enough.... So trifling a circumstance is often of great moment in the eyes of the Japanese who with so much zeal endeavour to fulfill their duties and blindly obey the laws issued forth by government, without understanding or explaining them in their own way, or making new ones suited to their own liking and circumstances." (ibid., p. 93)

Thunberg therefore also sees this aspect of Japanese character critically. Remarkably, he only presents this strict obedience to the law as negative when he is directly concerned himself. With regards to the Japanese, he claims that through the strict adherence to the law, liberty is granted to the Japanese (p.179).

Thunberg also points to the mistrust that Europeans encounter when dealing with the Japanese. Religious books are not allowed to be brought into the country and strict control is exercised about the goods that are taken into the country. To prevent contraband, the clothes of Europeans and Japanese are inspected whenever somebody enters or leave Deshima.

However, instead of characterizing this as a flaw of character, Thunberg explains this behavior by the dishonesty that the Europeans used to show in the past and continue doing so. 
"The Dutch themselves are the occasion of these over-rigorous searches, the strictness of which has been augmented on several different occasions till it has arrived at its present height... To all this may be added the pride which some of the weaker-minded officers in the Dutch service very impudently exhibit to the Japanese, by ill-timed contradiction, contemptuous behavior, scornful looks and laughter, which occasions the Japanese in their turn to hate and despise them - a hatred which is generally increased upon observing in how unfriendly and unmannerly a style they usually behave to each other." (Thunberg, 2005, p. 89)

This quote not only gives explanation for the Japanese mistrust but also illustrates Thunberg's opinion toward fellow Europeans in Japan, which is far from being positive." Although despising the Europeans, the Japanese still encounter Thunberg as respectful as they face their fellow citizens.

11 Thunberg scarcely writes about other Europeans in Japan. When he does so, however, his opinion is not well-disposed towards them: "The European way of living is in other respects the same as in other parts of India - luxurious and irregular ... and constitute a very disagreeable way of life, fit only for such as have no other way of spending their time than droning over a pipe of tobacco" (Thunberg, 2005, p. 104). 


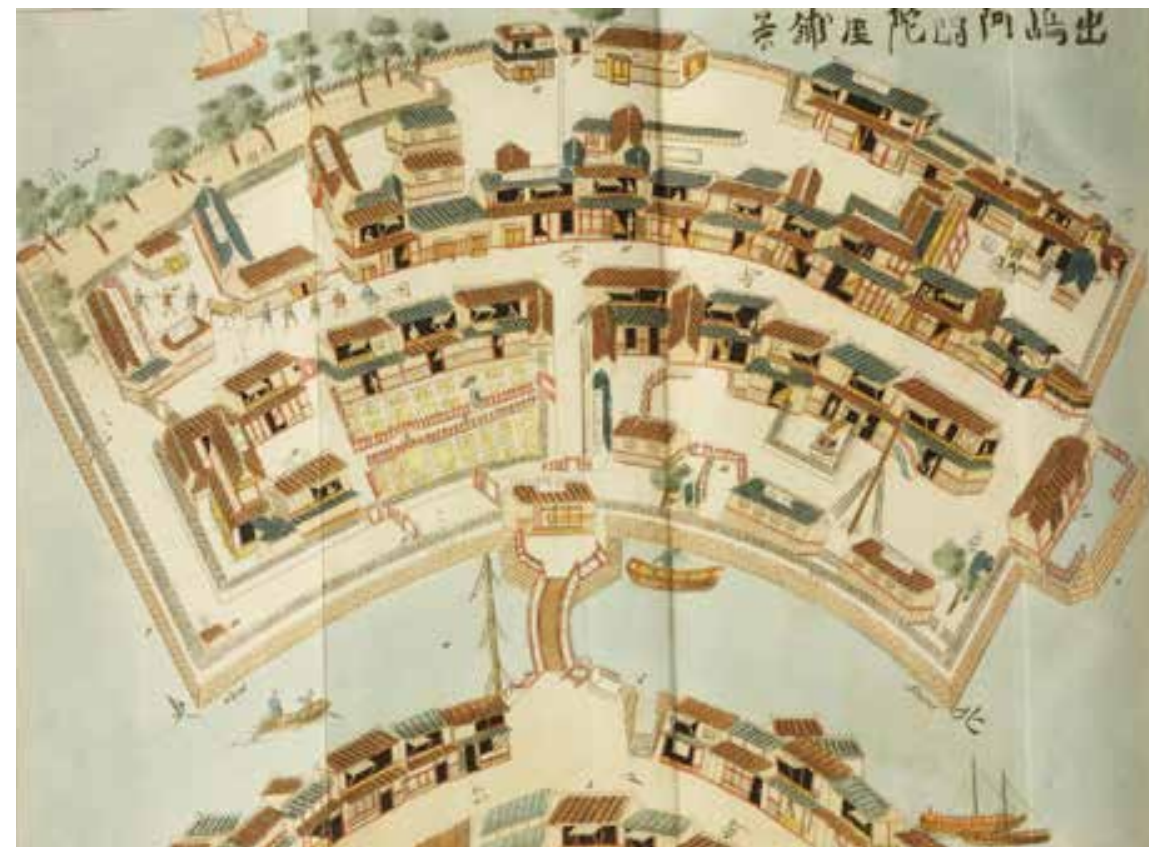

Fig. 3: Ground-plan of the Dutch trade-post ('factory') on the island Desima near Nagasaki.

Source:Titsingh, I. (1824-1825). Bijzonderheden over Japan, behelzende een verslag van de huwelijks plegtigheden, begrafenissen en feesten der Japanezen, de gedenkschriften der laatste Japansche keizers. 's-Gravenhage: Wed. J. Allart, p. 258. (also English edition, London 1822, p. 167).

Notably, when comparing different editions it becomes clear that not only the structure varies to a large degree from translation to translation (being much more comprised in the German translation by Sprengel, 1792). Depending on the version, also the general image of the Japanese varies: for instance, the quote above is left out by Sprengel. Therefore, the reader is unable to understand the harsh treatment by the Japanese, which leads to a slightly more negative picture of the Japanese in this German translation. Furthermore, Sprengel cut some paragraphs where Thunberg elaborates on, according to himself, important insights he had given the Japanese doctors (see above). Accordingly, one has to be cautious when examining different editions; comparing two or more different versions increases, of course, the validity of one's claims.

To conclude, Thunberg sets the Japanese apart from the Europeans by pointing toward the particularity of their character. This particularity is expressed through two 
main characteristics: curiosity towards European knowledge and commodities and subordination to law and superiors.

\section{Conclusion}

This chapter has given insight into the travel account by Carl Peter Thunberg at the end of the $18^{\text {th }}$ century. It has set the travel and Thunberg's written work into context and given insight into the publishing history of the book. Thunberg's journey took place between 1772 and 1779 and therefore fell into a time that a great number of scientists, traders and missionaries set out to explore other regions of the world. That the country of destination was Japan was by no means coincidence: Through his teacher Carl Linnaeus, Thunberg had contact to the Dutch East India Company (VOC), which was the only company that was permitted to trade in Japan. Since individual travelers were not allowed to enter the country, the VOC constituted the only means by which Japan could be reached.

As travelling within Europe had long been popular among aristocrats and the bourgeoisie already, no significant reputation could be gained through undertaking journeys within this region. Also on the Cape in Africa reports had been published. On Japan, the last scientific travel that had been done was by Engelbert Kaempfer nearly hundred years ago. The chance to explore Japan therefore seemed to promise to increased reputation among academia upon return.

In Japan, Thunberg encountered a respectful and friendly population, which he describes in a positive way in his travel account. Thunberg focuses particularly on the Japanese character. This, as he describes it, is marked by curiosity and inquisitiveness toward European knowledge. He views this characteristic extremely positive, albeit sometimes being irritated by their constant questions. Another trait of character is the strict obedience to rules and subordination to superiors. Although describing this mostly in a positive way, Thunberg is more ambiguous here. When this strict obedience is to his disadvantage, he criticizes the Japanese for not reflecting their actions and thoughtless taking over orders from superiors. Nevertheless, he admires this order when it does not affect himself. In general, it can be stated that Thunberg depicts a very positive image of the Japanese and differentiates them from Europeans by pointing toward their distinct character. 


\section{Bibliography}

Blomberg, C. (2008). 'Rerum memorabilium thesauros,' A treasury of memorable things Carl Peter Thunberg's oberservations during his years in Japan, 1775-1776. In W.F. Vande Walle \& K. Kasaya (Eds.). Dodonaeus in Japan. Translation and the Scientific Mind in the Tokugawa period (pp. 323-341). Leuven: Leuven University Press.

Eurostat (2012). Tourism in Europe: Results for 2011. Retrieved on June, $05^{\text {th }} 2013$, from http:// epp.eurostat.ec.europa.eu/cache/ITY_OFFPUB/KS-SF-12-028/EN/KS-SF-12-028-EN.PDF .

Friese, E. (1991). Reise durch einen Theil von Europa, Afrika und Asien: hauptsächlich in Japan in den Jahren 1770 bis 1779. Heidelberg: Manutius Verlag.

Hansen, L., Cormack, E. \& Thunberg, C.P. (2007). The Linnaeus Apostles. Global Science \& Adventure. Vol. 6: Europe, Southern Africa, East-, Southern- \& Southeast Asia: Carl Peter Thunberg. London [etc.]: IK Foundation.

Iggers, G.G., Wang, O.E. (2008). A Global History of Modern Historiography. Harlow: Pearson Education .

Jung, C. (2002). Kaross und Kimono. "Hottentotten" und Japaner im Spiegel des Reiseberichts von Carl Peter Thunberg (1743-1828). Stuttgart: Franz Steiner.

Kaempfer, E. (1727). The History of Japan, giving an Account of the ancient and present State and Government of that Empire; (etc., etc.) (J.C. Scheuchzer, Trans.) London: Published for translator.

Kent, N. (2008). A Concise History of Sweden. Cambridge: Cambridge University Press.

[Mavor, W.F.] (1809). Voyages to the Indian Seas and Japan, between the Years 1770 and 1779, by Charles Peter Thunberg. In W.F. Mayor (Ed.). A Collection of Voyages and Travels, from the Discovery of America to the Commencement of the Nineteenth Century (Vol. XI, pp. 253-372). London: Richard Phillips.

Rietbergen, P.J.A.N. (2004). Becoming famous in the eighteenth century. Carl-Peter Thunberg (1743-1828) between Sweden, the Netherlands and Japan. De achttiende eeuw: documentatieblad van de Werkgroep Achttiende Eeuw 36(1), 50-61, 64. 
Rietbergen, P.J.A.N. (2003). Japan verwoord. Nihon door Nederlands ogen, 1600-1799. Amsterdam: Hotei.

Rudner, I. \& Rourke, J. (1986). Biographical outline. In V.S. Forbes (Ed.). Carl Peter Thunberg, Travels at the Cape of Good Hope, 1772-1775: based on the English edition London 17931795. Cape Town: Van Riebeeck Society.

Screech, T. (2005). Japan Extolled and Decried:Carl Peter Thunberg and the Shogun's Realm, 1775-1796. Abingdon: Routledge.

Skott,C. (2010). The VOC and Swedish Natural History: the Transmission of Scientific Knowledge in the Eighteenth Century. In S. Huigen, J.L. de Jong, \& E. Kolfin (Eds.). The Dutch Trading Companies as Knowledge Networks (pp. 361-392). Leiden: Brill.

Sparrman, A. (1785). A Voyage to the Cape of Good Hope, Towards the Antarctic Polar Circle, and Round the World: but Chiefly into the Country of the Hottentots and Caffres, from the Year 1772, to 1776. Translated from the Swedish Original. Dublin: Messrs. White, Cash, and Byrne.

Thunberg, C. P. (1788-94). Resa uti Europa, Africa, Asia, förrättad åren 1770 - 1779. 3 Vols. Uppsala: Joh. Edman.

Thunberg, C.P. (1792). Karl Peter Thunbergs Reisen in Afrika und Asien, vorzüglich in Japan, während der Jahre 1772 bis 1779. Berlin : Vossischen Buchhandlung.

Thunberg, C.P. (1794). Voyage en Afrique et en Asie, principalement au Japon, pendant les années $1770-1779$. Paris: Fuchs.

Thunberg, C.P. (1794). Karl Peter Thunbergs Reise durch einen Theil von Europa, Afrika und Asien, hauptsächlich in Japan in den Jahren 1770 bis 1779. Berlin: Haude \& Spener.

Thunberg, C.P. (1795-96). Travels in Europe, Asia and Africa made during the Years 1770 \& 1779 ( $3^{\text {rd }}$ ed.). London : F. and C. Rivington.

Thunberg, C.P. (1796). Voyages de C.P. Thunberg, au Japon, par le cap de Bonne-Esperance, les Isles de la Sonde. Paris: Benoît Dandré, Garnery, Obré. 
Thunberg, C.P. (1928). Tsunberugu nihon kik . Tokyo: Sunnansha.

Thunberg, C.P. (1966). Le Japon du XVIIle siècle vu par un botaniste suèdois, Ch.-P.

Thunberg. Paris: Calmann-Lévy.

Thunberg, C.P. (1991). Reise durch einem Theil von Europa, Afrika und Asien. Heidelberg: Manutius.

Thunberg, C.P. (2005). Travels in Europe, Asia and Africa made during the Years 1770 \& 1779. In: Screech, T. (Ed.). Japan Extolled and Decried: Carl Peter Thunberg and the Shogun's Realm, 1775-1796. Abingdon: Routledge. 


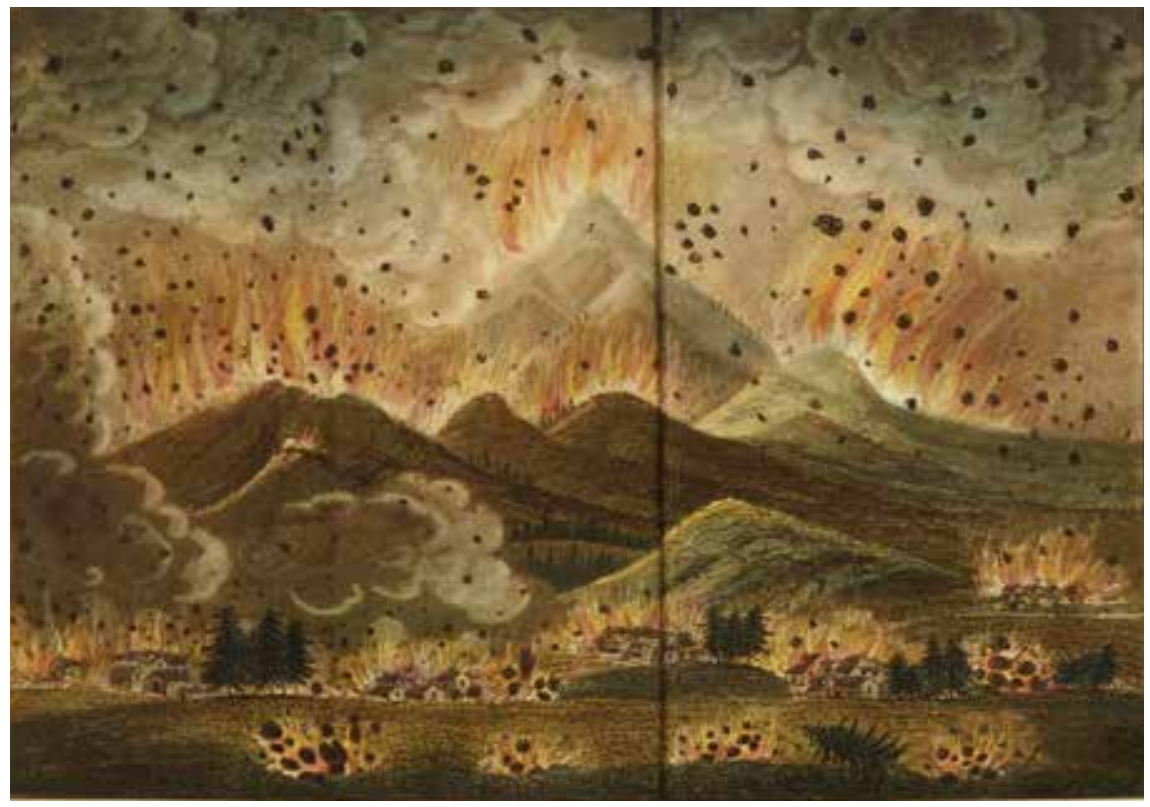

The eruption of the volcano Asama-yama, Honshu, in 1783, as reported by Isaac Titsingh.

Source:Titsingh, I. (1824-1825). Bijzonderheden over Japan, behelzende een verslag van de huwelijks plegtigheden, begrafenissen en feesten der Japanezen, de gedenkschriften der laatste Japansche keizers. 's-Gravenhage: Wed. J. Allart. (also English edition, London 1822, pp. 100-101). 